\title{
Perbandingan Waktu Awitan dan Lama Kerja Kombinasi Bupivakain 0,5\% dan Lidokain 2\% dengan Bupivakain 0,5\% pada Blokade Infraklavikular untuk Operasi Lengan Bawah
}

\author{
Andy Pawana Destiara, ${ }^{1}$ Dedi Fitri Yadi, ${ }^{2}$ Rudi Kurniadi Kadarsah ${ }^{2}$ \\ ${ }^{1}$ Rumah Sakit Umum Daerah Kota Bekasi, ${ }^{2}$ Departemen Anestesiologi dan Terapi Intensif \\ Fakultas Kedokteran Universitas Padjadjaran/Rumah Sakit Dr. Hasan Sadikin Bandung
}

\begin{abstract}
Abstrak
Penggunaan kombinasi obat anestesi lokal bupivakain dan lidokain dapat menghasilkan waktu awitan yang cepat dan lama kerja yang panjang. Penelitian ini bertujuan membandingkan waktu awitan dan lama kerja kombinasi bupivakain 0,5\% dan lidokain $2 \%$ dengan bupivakain $0,5 \%$ pada blokade infraklavikular untuk pembedahan lengan bawah. Penelitian menggunakan uji klinis acak terkontrol buta ganda terhadap 36 pasien dewasa usia 18-60 tahun yang menjalani pembedahan lengan bawah dan dilakukan blokade infraklavikular dengan panduan nerve stimulator di Rumah Sakit Dr. Hasan Sadikin Bandung selama periode April-Juni 2015. Pasien dibagi dalam dua kelompok, kelompok bupivakain dan lidokain (BL) dan bupivakain (B). Analisis stastistik menggunakan student's t-test, chi-square, Eksak Fisher, Kolmogorov Smirnov dan MannWhitney U-test. Hasil penelitian didapatkan waktu awitan blokade sensorik dan motorik pada kelompok BL, yaitu 7,1 \pm 2 menit dan 10,9 $\pm 5,3$ menit, pada kelompok B, yaitu 19,8 $\pm 4,5$ menit dan $29 \pm 7,7$ menit. Lama kerja blokade sensorik dan motorik pada kelompok BL, yaitu 540,9 $\pm 195,1$ menit dan 445,6 6158,9 menit, pada kelompok B, yaitu 837,6 $\pm 376,6$ menit dan $653,9 \pm 304,3$ menit. Simpulan, kombinasi bupivakain $0,5 \%$ dan lidokain $2 \%$ menghasilkan awitan blokade sensorik serta motorik lebih cepat dan lama kerja yang lebih singkat dibanding dengan bupivakain $0,5 \%$.
\end{abstract}

Kata kunci: Blokade infraklavikular, kombinasi bupivakain-lidokain, bupivakain, lama kerja blokade, waktu awitan blokade

\section{Comparison of Onset and Duration of Action between 0.5\% Bupivacaine and 2\% Lidocaine Combination and 0.5\% Bupivacaine on Infraclavicular Block for Forearm Surgery}

\begin{abstract}
The combination of local anesthetic drugs bupivacaine and lidocaine can produce rapid onset and long duration of action. The purpose of this study was to compare the onset and duration of action between $0.5 \%$ bupivacaine and $2 \%$ lidocaine combination and $0.5 \%$ bupivacaine on infraclavicular block for forearm surgery. This study was conducted using a randomized double blind controlled clinical trial on 36 adult patients aged 18-60 years who underwent forearm surgery under infraclavicular block using nerve stimulator guidance in Dr. Hasan Sadikin General Hospital between the period of April to June 2015. Patients were divided into two groups: patients in bupivacaine and lidocaine (BL) group and bupivacaine (B)group. The statistical analysis were performed using the student's t-test, chi-square, Fisher's Exact, Kolmogorov Smirnov, and Mann-Whitney U-test. The onsets of sensory and motor blocks in BL group were 7.1 \pm 2 min and $10.9 \pm 5.3 \mathrm{~min}$, repectively and B group were $19.8 \pm 4.5 \mathrm{~min}$ and $29 \pm 7.7 \mathrm{~min}$, respectively. The durations of sensory and motor blocks in BL group were $540.9 \pm 195.1 \mathrm{~min}$ and $445.6 \pm 158.9 \mathrm{~min}$ and B group were $837.6 \pm 376.6 \mathrm{~min}$ and $653.9 \pm 304.3 \mathrm{~min}$. This study reveals that the combination of $0.5 \%$ bupivacaine and $2 \%$ lidocaine in infraclavikular block had a faster onset of sensory and motor blocks compared to $0.5 \%$ bupivacaine and a shorter duration of action compared to $0.5 \%$ bupivacaine.
\end{abstract}

Key words: Bupivacaine, combination of bupivacaine-lidocain, duration of block, infraclavicular block, onset of block

Korespondensi: Andy Pawana Destiara, dr., SpAn, Rumah Sakit Umum Daerah Kota Bekasi, Jl. Pramuka No. 55 Bekasi/ Jl. Sultan Agung No. 37. RT. 04 RW. 01 Kota Baru Bekasi, Mobile 081218186587,Email andypawana@yahoo.com 


\section{Pendahuluan}

Pembedahan pada daerah tangan, pergelangan tangan, lengan bawah, dan lengan atas dapat dilakukan dalam anestesi regional maupun anestesi umum. Blokade pleksus brakialis merupakan teknik anestesi regional yang dapat dilakukan dengan teknikyang bervariasi untuk pembedahan ekstremitas atas. ${ }^{1,2}$ Penggunaan blokade pleksus brakialis memiliki beberapa kelebihan dibanding dengan anestesi umum, yaitu menurunkan risiko mual dan muntah, tidak mengganggu hemodinamik, merupakan pilihan utama untuk pasien yang tidak dapat dilakukan anestesi umum, bebas nyeri lebih lama, waktu pemulihan lebih cepat, waktu perawatan yang lebih singkat, dan biaya yang dikeluarkan menjadi lebih sedikit. ${ }^{3}$

Blokade infraklavikular merupakan pilihan yang baik dalam menghasilkan anestesi untuk ekstremitas atas terutama pada lengan bawah. Teknik ini mudah dan aman untuk dilakukan. Salah satu faktor yang berpengaruh terhadap blokade ini adalah obat anestesi lokal yang digunakan. ${ }^{4-6}$

Obat anestesi lokal menyebabkan blokade konduksi impuls saraf yang bersifat reversibel pada jalur saraf sentral maupun perifer setelah dilakukan anestesi regional. Penggunaan obat anestesi lokal yang tepat akan menyebabkan impuls saraf autonom, sensorik, dan motorik terhambat sehingga menghasilkan blokade sistem saraf pada daerah saraf yang terpapar. Penggunaan teknik anestesi lokal juga harus memperhitungkan dosis obat anestesi lokal yang digunakan supaya tidak terjadi toksisitas sistemik dan mengetahui karakteristik obat seperti awitan, lama kerja, derajat blokade, dan volume yang dibutuhkan., $3,-10$

Bupivakain adalah anestetik lokal golongan amida yang dapat digunakan untuk anestesi regional karena membrikan lama kerja yang panjang. Bupivakain memiliki ikatan protein yang tinggi dan nilai pKa sebesar 8,1 sehingga mempunyai lama kerja yang panjang, namun memiliki waktu awitan yang lambat. ${ }^{3,9}$

Berbagai penelitian telah dilakukan dengan memberikan obat-obat tambahan terhadap anestetik lokal pada blokade pleksus brakialis untuk menghasilkan waktu awitan yang cepat dan juga lama kerja yang panjang. Salah satu penelitian memakai kombinasi anestetik lokal bupivakain serta lidokain untuk mendapatkan hasil yang diinginkan, yaitu waktu awitan cepat dan lama kerja blokade sensorik yang panjang untuk analgesik, namun lama kerja blokade motorik lebih singkat sehingga ekstremitas dapat segera digerakkan.

Suatu penelitian membandingkan antara efek penggunaan kombinasi anestetik lokal bupivakain $0,5 \%$ dan lidokain $2 \%$ dengan bupivakain $0,5 \%$ terhadap waktu awitan dan lama kerja blokade pada blokade saraf femoral dan skiatik. Pada kombinasi bupivakain 0,5\% dan lidokain $2 \%$ didapatkan waktu awitan blokade sensorik dan motorik 15 menit dan lama kerja blokade sensorik dan motorik 12 jam. Sementara pada bupivakain $0,5 \%$, waktu awitan blokade sensorik dan motorik 30 menit dan lama kerja blokade sensorik 22 jam dan motorik 18 jam. ${ }^{11}$

Penelitian lain membandingkan kombinasi bupivakain $0,5 \%$ dan lidokain $2 \%$ dengan bupivakain $0,5 \%$ pada blokade infraklavikular. Pada penggunaan kombinasi bupivakain 0,5\% dan lidokain $2 \%$ didapatkan waktu awitan 4 menit untuk blokade sensorik serta motorik dan lama kerja 6,1 jam. Pada bupivakain 0,5\% didapatkan waktu awitan 9,7 menit dan lama kerja 4,4 jam. $^{12}$

Penelitianini merupakanulangan penelitian sebelumnya yang telah dilakukan di Turki pada tahun 2013, namun dengan perbedaan volume obat anestesi lokal yang diberikan. ${ }^{12}$ Tujuan penelitian ini adalah menilai perbandingan waktu awitan dan lama kerja bupivakain 0,5\% dengan kombinasi bupivakain 0,5\% dan lidokain $2 \%$ pada blokade infraklavikular untuk pembedahan lengan bawah.

\section{Subjek dan Metode}

Penelitian ini dilakukan dengan cara prospektif eksperimental dengan uji klinis acak terkontrol buta ganda. Subjek penelitian adalah pasien yang menjalani pembedahan pada lengan bawah di Rumah Sakit Dr. Hasan Sadikin Bandung pada bulan April-Juni 2015. Kriteria 
inklusi adalah pasien yang menjalani operasi lengan bawah dengan blokade infraklavikular, usia 18-60 tahun, serta berat badan 70-80 kg. Kriteria eksklusi adalah pasien tidak kooperatif, mendapatkan obat antikoagulan atau terdapat gangguan faktor pembekuan, alergi terhadap anestetik lokal, mempunyai kelainan sensorik dan motorik, serta terdapat infeksi lokal di area penyuntikan. Sampel dikeluarkan dari penelitian apabila dalam waktu 45 menit setelah penyuntikan obat ke dalam pleksus brakialis tidak terjadi blokade sensorik.

Besar sampel ditentukan mempergunakan rumus penelitian analisis kategorik numerik yang tidak berpasangan. Pengambilan sampel pasien dilakukan secara consecutive sampling dengan alokasi subjek ke dalam salah satu kelompok dilakukan secara acak sederhana dengan menggunakan randomisasi blok acak. Didapatkan jumlah sampel sebanyak 18 orang untuk tiap kelompok sehingga besar semua sampel adalah 36 orang.

Setelah mendapatkan persetujuan dari Komite Etik Penelitian Kesehatan Fakultas Kedokteran Universitas Padjadjaran/Rumah Sakit Dr. Hasan Sadikin Bandung, pasien yang telah memenuhi kriteria inklusi diberikan penjelasan tentang prosedur yang dijalani. Sampel dibagi ke dalam dua kelompok secara acak dengan tiap kelompok terdiri atas 18 pasien. Kelompok bupivakain dan lidokain (BL) mendapatkan bupivakain 0,5\% sebanyak $12,5 \mathrm{~mL}$ dicampurkan dengan lidokain $2 \%$ sebanyak 12,5 mL dan ditambahkan epinefrin 1:200.000, sedangkan kelompok bupivakain (B) mendapatkan bupivakain 0,5\% sebanyak $25 \mathrm{~mL}$.

Pasien dipasang alat pantau tekanan darah, laju nadi, laju napas, dan juga saturasi oksigen. Selanjutnya, dipasang kateter intravena pada tangan yang berlawanan dengan yang akan dilakukan blokade dan pembedahan.

Pasien diposisikan terlentang. Tangan yang akan dilakukan blokade diletakkan diabdomen. Akromion serta sternal notch diidentifikasi. Lokasi tusukan jarum ditandai dengan titik tengah di antara akromion dan sternal notch tepat di bawah tulang klavikula. Sebelum dilakukan blokade terlebih dahulu diberikan premedikasi midazolam $1 \mathrm{mg}$ intravena (i.v.), fentanil 50 mg i.v., dan dilakukan tindakan aseptik dan antiseptik.

Sesuai dengan teknik vertical infraclavicular block, jarum diinsersikan di bawah titik tengah klavikula di antara jugular notch dan akromion. Blokade infraklavikular dilakukan memakai bantuan nerve stimulator menggunakan jarum insulasi, $50 \mathrm{~mm}, 22 \mathrm{G}$ teflon coated stimulating needle (stimuplex, B Braun, Germany). Nerve stimulator dihubungkan ke jarum insulasi dan diatur untuk memberikan arus 1,0 mA pada frekuensi $2 \mathrm{~Hz}$ dan durasi pulsasi 0,1 ms. Jarum ditusukkan dengan posisi vertikal terhadap bidang datar dan stimulasi diberikan sebesar 1,0 mA. Setelah diperoleh gerakan ekstensi/ fleksi pada jari-jari tangan maka stimulasi diperkecil hingga 0,3 hingga 0,5 mA dan masih kontraksi. Sebelumnya dilakukan aspirasi untuk memastikan tidak terdapat kesalahan penyuntikan obat ke dalam pembuluh darah, anestetik lokal diberikan secara bertahap, dan dilakukan aspirasi secara berkala tiap 5-25 $\mathrm{mL}$.

Waktu mulai dihitung segera setelah obat anestesi lokal disuntikkan seluruhnya dan dievaluasi setiap menit hingga 45 menit oleh seorang pengamat. Blokade sensorik di daerah yang dipersarafi oleh saraf muskulokutaneus, yaitu sisi radial lengan bawah, saraf radialis adalah bagian dorsal ibu jari, saraf medialis dan ulnaris, yaitu bagian palmar jari telunjuk dan jari kelingking dinilai dengan melakukan pin prick menggunakan jarum 19G, kemudian dibandingkan dengan tangan yang tidak mendapatkan perlakuan. Blokade sensorik ditentukan dengan skala penilaian 3 angka: 0 sensasi normal, 1 sensasi tumpul, 2 hilangnya sensasi. Blokade motorik ditentukan dengan cara meminta pasien melakukan gerakan fleksi pergelangan tangan dan lengan bawah. Blokade motorik ditentukan memakai skala penilaian 3 angka: 0 kekuatan otot normal, 1 kekuatan otot berkurang, 2 tidak ada kekuatan otot. Setiap waktu dicatat saat skala 2 tercapai.

Lama kerja blokade sensorik dihitung hingga saat pertama kali pasien meminta obat analgesik dengan skor numeric rating scale lebih dari 3. Lama kerja blokade motorik 
Tabel 1 Karakteristik Umum Subjek Penelitian

\begin{tabular}{|c|c|c|c|}
\hline \multirow[b]{2}{*}{ Variabel } & \multicolumn{2}{|c|}{ Kelompok } & \multirow[b]{2}{*}{ Nilai p } \\
\hline & $\begin{array}{c}\text { Bupivakain } \\
(\mathrm{n}=18)\end{array}$ & $\begin{array}{c}\text { Bupivakain + Lidokain } \\
(\mathrm{n}=18)\end{array}$ & \\
\hline \multicolumn{4}{|l|}{ Usia (tahun) } \\
\hline Rata-rata (Std. deviasi) & $33,6(12,8)$ & $35,6(12,7)$ & $0,651^{*}$ \\
\hline Range & $18-57$ & $18-54$ & \\
\hline \multicolumn{4}{|l|}{ Jenis kelamin } \\
\hline Laki-laki & 12 & 10 & $0,494^{* *}$ \\
\hline Perempuan & 6 & 8 & \\
\hline \multicolumn{4}{|l|}{ Berat badan (kg) } \\
\hline Rata-rata (Std. deviasi) & $63,7(8,8)$ & $61,7(9,6)$ & $0,518^{* * *}$ \\
\hline Range & $50-74$ & $50-79$ & \\
\hline Pedidikan & & & $0,766^{* *}$ \\
\hline SMP & 9 & 5 & \\
\hline SMA & 7 & 12 & \\
\hline D3 & 1 & 0 & \\
\hline S1 & 1 & 1 & \\
\hline
\end{tabular}

Keterangan: uji statistik dengan Mann Whitney Test*, chisquare $^{* *}$ dan $t$-test***. Bermakna jika nilai $\mathrm{p}<0,05$

dihitung hingga saat pertama kali pasien dapat menggerakkan ekstremitasnya. Pasien tidak mendapatkan analgesik setelah operasi hingga pasien dapat merasa nyeri kembali.

Analisis stastistika data memakai student's t-test, chi-square, Exact Fisher, Kolmogorov Smirnov, serta Mann-Whitney U-test dengan tingkat kepercayaan sebesar 95\% dan dianggap bermakna bila $\mathrm{p}<0,05$. Data disajikan dalam rata-rata (mean) dan dianalisis menggunakan perangkat lunak statistical product and service solutions (SPSS) 21.0.

\section{Hasil}

Hasil analisis statistika menunjukkan variabel jenis kelamin, usia, dan pendidikan pada kedua kelompok perlakuan tidak berbeda bermakna ( $p>0,05$ dan Tabel 1).

Berdasarkan hasil uji statistikmenggunakan

Tabel 2 Waktu Awitan Blokade Sensorik dan Motorik

\begin{tabular}{|c|c|c|c|}
\hline \multirow{2}{*}{$\begin{array}{l}\text { Waktu } \\
\text { Awitan }\end{array}$} & \multicolumn{2}{|c|}{ Perlakuan } & \multirow{2}{*}{ Nilai p } \\
\hline & Bupivakain & Bupivakain + Lidokain & \\
\hline \multicolumn{4}{|l|}{ Blokade sensorik } \\
\hline Rata-rata (menit) & 19,8 & 7,1 & $0,001^{*}$ \\
\hline Std Deviasi & 4,5 & 2 & \\
\hline \multicolumn{4}{|l|}{ Blokade motorik } \\
\hline Rata-rata (menit) & 29 & 10,9 & $0,001^{*}$ \\
\hline Std Deviasi & 7,7 & 5,3 & \\
\hline
\end{tabular}

Keterangan: Uji statistik dengan Mann-Whitney *. Bermakna jika nilai $p<0,05$ 


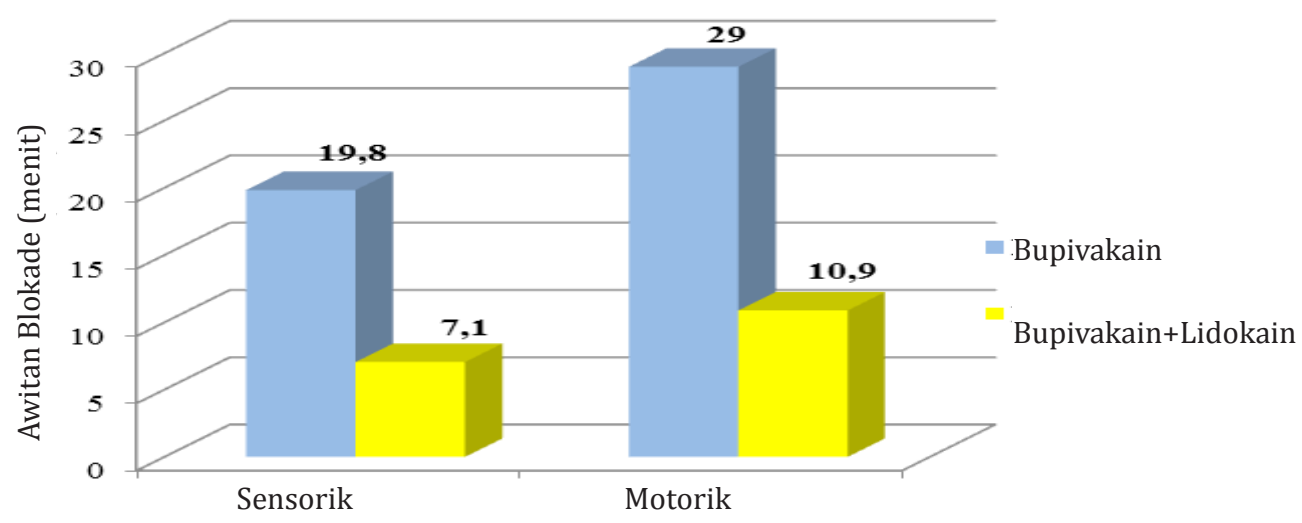

Gambar 1 Perbandingan Waktu Awitan Blokade Sensorik dan Motorik Pemberian Kombinasi Bupivakain 0,5\% dan Lidokain 2\% dengan Bupivakain 0,5\% pada Blokade Infraklavikular

Uji Mann-Whitney menunjukkan waktu awitan blokade sensorik dan motorik pada kelompok kombinasi bupivakain $0,5 \%$ dan lidokain $2 \%$ lebih cepat secara bermakna dibanding dengan bupivakain 0,5\% (Tabel 2 dan Gambar 1).

Berdasarkan hasil uji statistikmenggunakan Uji Mann-Whitney menunjukkan bahwa lama kerja blokade sensorik dan motorik antara kelompok kombinasi bupivakain 0,5\% dan lidokain 2\% lebih singkat secara bermakna dibanding dengan bupivakain 0,5\% (Tabel 3 dan Gambar 2).

\section{Pembahasan}

Berdasarkan hasil uji statistika memakai Uji
Mann-Whitney, pada penelitian ini didapatkan bahwa waktu awitan blokade sensorik dan motorik lebih cepat bermakna pada kelompok kombinasi bupivakain 0,5\% dan lidokain 2\% dibanding dengan kelompok bupivakain $0,5 \%$ tunggal dengan nilai $p=0,001$ untuk tiap-tiap waktu awitan blokade sensorik dan motorik (Tabel 2).

Penelitian ini membandingkan antara waktu awitan blokade mempergunakan bupivakain 0,5\% dibanding dengan kombinasi bupivakain $0,5 \%$ dan lidokain $2 \%$ pada blokade femoralis dan skiatik, didapatkan waktu awitan blokade sensorik dan motorik $28 \pm 12$ menit pada kelompok bupivakain 0,5\%. Sementara pada kelompok kombinasi bupivakain 0,5\% dan lidokain 2\% waktu awitan blokade sensorik

Tabel 3 Lama Kerja Blokade Sensorik dan Motorik

\begin{tabular}{lccc}
\hline \multirow{2}{*}{ Lama Kerja } & \multicolumn{2}{c}{ Kelompok } & \multirow{2}{*}{ Nilai p } \\
\cline { 2 - 3 } & Bupivakain & Bupivakain + Lidokain & \\
\hline Blokade sensorik & & & \multirow{2}{*}{$0,007^{*}$} \\
Rata-rata (menit) & 837,6 & 540,9 & \\
Std Deviasi & 376,5 & 195,1 & \multirow{2}{*}{$0,022^{*}$} \\
Blokade motorik & & & \\
Rata-rata (menit) & 653,9 & 445,6 & 158,9 \\
Std Deviasi & 304,3 & 150,9 & \\
\hline
\end{tabular}

Keterangan: uji statistik dengan Mann-Whitney Test*. Bermakna jika nilai $\mathrm{p}<0,05$ 


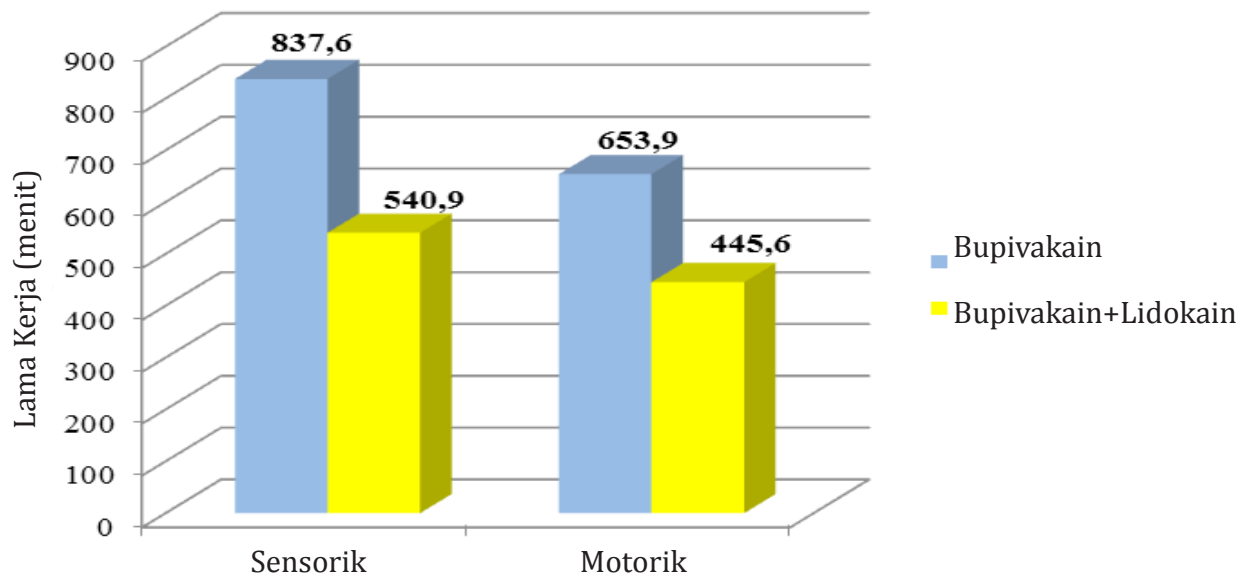

Gambar 2 Perbandingan Lama Kerja Blokade Sensorik dan Motorik Pemberian Kombinasi Bupivakain 0,5\% dan Lidokain 2\% dengan Bupivakain 0,5\% pada Blokade Infraklavikular

dan motorik $16 \pm 9$ menit. Hasil tersebut serupa dengan penelitian Cuvillon dkk. ${ }^{11}$ yaitu waktu awitan blokade lebih cepat pada kelompok kombinasi bupivakain dan lidokain.

Penelitian ini juga membandingkan waktu awitan blokade antara pemakaian bupivakain $0,5 \%$ dibanding dengan kombinasi bupivakain $0,5 \%$ dan lidokain $2 \%$ pada teknik blokade infraklavikular. Didapatkan waktu awitan blokade sensorik dan motorik 9,7 $\pm 1,8$ menit pada kelompok bupivakain 0,5\%. Sementara, pada kelompok kombinasi bupivakain 0,5\% dan lidokain $2 \%$ dengan waktu awitan blokade sensorik dan motorik adalah 4 $\pm 1,3$ menit. Hasil tersebut serupa dengan penelitian Ozmen dkk., ${ }^{12}$ yaitu waktu awitan blokade lebih cepat pada kelompok kombinasi bupivakain dan lidokain. Hal ini terjadi karena perbedaan $\mathrm{pKa}$ larutan bupivakain dengan larutan kombinasi bupivakain dan lidokain. Nilai pKa larutan kombinasi bupivakain dan lidokain lebih mendekati $\mathrm{pH}$ fisiologis sehingga konsentrasi basa yang tidak terkonjugasi lebih tinggi dan menyebabkan waktu awitan lebih cepat dibanding dengan kelompok bupivakain. ${ }^{1,13}$

Pada penelitian ini didapatkan pula bahwa lama kerja blokade sensorik dan motorik lebih singkat secara bermakna $(\mathrm{p}<0,05)$ pada kelompok kombinasi bupivakain $0,5 \%$ dan lidokain $2 \%$ dibandingkan dengan kelompok bupivakain 0,5\% (Tabel 3).
Penelitian lain yang membandingkan lama kerja blokade menggunakan bupivakain 0,5\% dibandingkan dengan kombinasi bupivakain $0,5 \%$ dan lidokain $2 \%$ pada blokade femoralis dan skiatik, didapatkan lama kerja blokade sensorik 22 jam dan motorik 18 jam pada kelompok bupivakain 0,5\%. Sementara, pada kelompok kombinasi bupivakain 0,5\% dan lidokain $2 \%$ waktu awitan blokade sensorik dan motorik 12 jam. Hasil tersebut serupa dengan penelitian Cuvillon dkk., ${ }^{11}$ yaitu waktu awitan blokade lebih cepat pada kelompok kombinasi bupivakain dan lidokain.

Lama kerja blokade sensorik dan motorik didapatkan waktu yang lebih singkat pada kelompok kombinasi bupivakain dan lidokain dikarenakan dosis bupivakain pada kelompok kombinasi tersebut lebih kecil dibandingkan dengan kelompok bupivakain sehingga waktu untuk mengeliminasi anestetik lokal dari saraf dan jaringan sekitar lebih cepat pada kelompok kombinasi bupivakain dan lidokain. ${ }^{14}$

Penggunaan epinefrin 1:200.000 pada larutan kombinasi bupivakain dan lidokain pada penelitian ini ditujukan menghindari efek toksik anestetik lokal yang aditif apabila terjadi penggabungan antara sesama obat anestetik lokal. Pada larutan kombinasi bupivakain dan lidokain apabila dihitung maka akan tercapai dosis toksik pada larutan kombinasi tersebut, oleh karena itu epinefrin diberikan untuk 
meningkatkan ambang batas toksik lidokain dari 4,5 $\mathrm{mg} / \mathrm{kgBB}$ menjadi $7 \mathrm{mg} / \mathrm{kgBB}$ sehingga masih berada di rentang yang aman. Pada kelompok bupivakain tidak diberikan epinefrin karena dosis yang digunakan tidak mencapai dosis toksik. Epinefrin juga dapat berpengaruh pada lama kerja anestetik lokal karena efek vasokontriksi pembuluh darah sehingga mengakibatkan obat anestetik lokal kontak lebih lama dengan jaringan saraf dan penyerapan ke dalam darah akan semakin lambat sehingga proses eliminasi juga akan lebih lama. Namun, meskipun epinefrin dapat memperpanjang lama kerja anestetik lokal, efeknya lebih efektif terlihat pada penggunaan dengan anestetik lokal kerja sedang seperti lidokain dibanding dengan obat anestetik lokal kerja panjang seperti bupivakain. ${ }^{14,15}$

Pada penelitian di Skandinavia didapatkan hasil bahwa epinefrin sebagai obat tambahan pada anestetik lokal tidak memperpanjang lama kerja pada blokade infraorbita terhadap tikus. ${ }^{16}$

Hasil penelitian lain di Amerika didapatkan bahwa penggunaan tambahan epinefrin pada bupivakain untuk anestesi epidural terhadap anjing tidak berpengaruh terhadap lama kerja. ${ }^{17}$ Berdasarkan hasil tersebut dapat disimpulkan bahwa penambahan epinefrin pada kelompok bupivakain dan lidokain tidak menyebabkan bias pada hasil penelitian ini. Pada penelitian ini didapatkan bahwa lama kerja blokade sensorik dan motorik lebih singkat secara bermakna pada kelompok kombinasi bupivakain $0,5 \%$ dan lidokain $2 \%$ dibanding dengan kelompok bupivakain $0,5 \%$ yang artinya bahwa tidak terlihat efek pemanjangan lama kerja akibat penggunaan epinefrin pada larutan kombinasi.

\section{Simpulan}

Berdasarkan hasil penelitian dan pembahasan di atas maka dapat ditarik simpulan bahwa kombinasi bupivakain 0,5\% dan lidokain 2\% menghasilkan awitan blokade sensorik dan motorik lebih cepat dan lama kerja yang lebih singkat dibanding dengan bupivakain 0,5\%.

\section{Daftar Pustaka}

1. Morgan GE, Mikhail M, Murray M. Clinical anesthesiology. Edisi ke-4. New York: McGraw-Hill; 2006.

2. Coskun D, Mahli A. The extent of blockade following axillary, supraclavicular, and interscalene approaches of brachial plexus block. Turk J Med Sci. 2011;41:623-31.

3. Alici HA, Cesur $M$, Kürşad H, Doğan N, Yüksek MŞ. Possible subdural block during interscalene brachial plexus block: a case report. EAJM. 2008;40:98-101.

4. Chin KJ, Alakkad H, Adhikary SY, Singh M. Infraclavicular brachial plexus block for regional anesthesia of the lower arm (review). The Cochrane Collaboration. 2013;8:1-83.

5. McDonald SB. Brachial plexus blocks. Dalam: Mulroy MF, Bernards CM, McDonald SB, Salinas FV, penyunting. Regional anesthesia. Edisi ke-4. Philadelphia: Lippincott Williams \& Wilkins; 2009. hlm. 172-202.

6. Macfarlane A, Anderson K. Infraclavicular brachial plexus blocks. Continuing Education in Anesthesia. Crit Care Pain. 2009;9:139-43.

7. Stoelting RK. Pharmacology and physiology anaestetic practice. Edisi ke-4. Philadelphia: Lippincott Raven; 2006.

8. Berde CB, Strichartz GR. Local anesthetics. Dalam: Miller RD, penyunting. Miller's anesthesiology. Edisi ke-7. USA: Churchill Livingstone Elsevier; 2009. hlm. 913-39.

9. Liu SS, Lin Y. Local anesthetic. Dalam: Barash PG, Cullen BF, Stoelting RK, Cahalan MK, Stock MC, penyunting. Clinical anesthesia. Edisi ke-6. Philadelphia: Lippincott Williams \& Wilkins; 2009. hlm. 531-48.

10. O'Donnel BD, Iohom G. An estimation of the minimum effective anesthetic volume of $2 \%$ lidocaine in ultrasound-guided axillary brachial plexus block. Anesthesiology. 2009;111:25-9.

11. Cuvillon P, Nouvellon E, Ripart J, Boyer JC, Dehour L, Mahamat A, dkk. A comparison of the pharmacodynamics 
and pharmacokinetics of bupivacaine, ropivacaine (with epinephrine) and their equal volumee mixtures with lidocaine used for femoral and sciatic nerve blocks: a double-blind randomized study. International Anesth Res Soc. 2009;108:641-9.

12. Ozmen O, Alici HA, Celik M, Dostbil A, Cesur M. The effect of addition of lidocaine to bupivacaine on anesthesia beginning time, block time, and block quality in lateral sagittal infraclavicular block. Turk J Med Sci. 2013;43:542-7.

13. Nysora. Local anesthetics: clinical pharmacology and rational selection [dokumen di internet]. 2013 [diunduh 1 Juli 2015]. Tersedia dari: http://www.nysora. $\mathrm{com} / \mathrm{regional}$-anesthesia/foundationsof-ra/3492-local-anesthetics-clinicalpharmacology-and-rational-selection. html

14. Bernard CM. Local anesthetics. Dalam:
Mulroy MF, Bernard CM, McDonald SB, Salinas FV, penyunting. Regional anesthesia. Edisi ke-4. Philadelphia: Lippincott Williams \& Wilkins; 2009. hlm. $1-10$.

15. Neal JM, Gerancher JC, Hebl JR, Ilfeld BM, McCartney CJL, Franco CD, dkk. Upper extremity regional anesthesia: essentials of our current understanding. Reg Anesth Pain Med. 2009;34:134-70.

16. Renck H, Hassan HG. Epinephrine as an adjuvant to amino-amide local anesthetics does not prolong their duration of action in infraorbital nerve block in the rat. Acta Anaesthesiol Scand. 1992;36:387-92.

17. Hurley RJ, Arthur RG, Feldman HS, Covino BG, Latka CAS. The effects of epinephrine on the anesthetic and hemodynamic properties of ropivacaine and bupivacaine after epidural administration in the dog. Reg Anesth. 1991;16:303-8. 